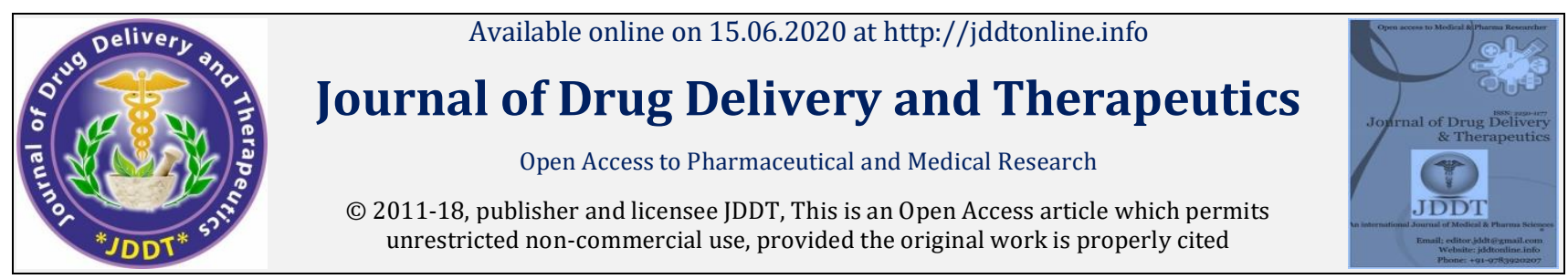

Open 1 Access

Review Article

\title{
Immunomodulators for Curtailing COVID-19: a Positive Approach
}

\author{
Shabir Ahmad Bhat*1, Shameem Ahmad Rather ${ }^{2}$, Arsheed Iqbal ${ }^{3}$, Haider Ali Qureshi' ${ }^{1}$, Naquibul Islam ${ }^{4}$ \\ ${ }^{1}$ MD Scholar, Department of Moalajat, Regional Research Institute of Unani Medicine, University of Kashmir, Srinagar, J\&K, India \\ ${ }^{2}$ Reader, Department of Moalajat, Regional Research Institute of Unani Medicine, University of Kashmir, Srinagar, J\&K, India \\ ${ }^{3}$ Scientist III, Regional Research Institute of Unani Medicine, University of Kashmir, Srinagar, J\&K, India \\ ${ }^{4}$ Head of the department, Moalajat, Regional Research Institute of Unani Medicine, University of Kashmir, Srinagar, J\& K, India
}

\begin{abstract}
Severe acute respiratory syndrome coronavirus-2 (SARS-CoV-2) is highly infectious, spreading swiftly from man to man which has not been previously recognized in humans. World Health Organization (WHO) on February 11, 2020 named the infection as COVID-19 as an acronym for 'coronavirus disease-2019' and on March 11, 2020 declared the outbreak as pandemic. It affects all the people without discrimination, however, older, immune compromised are more susceptible. The virus chiefly spread through droplet infection from infected person to healthy one by coughing, sneezing or with infected hands when touched to eyes, nose or mouth. Symptoms of the infection range from mild to s evere ones. In severe cases (approx. 14\% of cases) fever typically of high grade (104 $\mathrm{F}$ ), breathlessness, pneumonia and severe acute respiratory syndrome may appear. So far no specific treatment or vaccine for novel coronavirus-2019 is there. From the past and recent past experiences we have learnt that herbal medicines have proven beneficial against various dreadful viral infections. Assessment of immune enhancing herbs in this paper may definitely be helpful for the body to fight COVID-19 infection.
\end{abstract}

Keywords: Severe acute respiratory syndrome coronavirus-2, COVID-19, Pneumonia, Immune, Herbs

Article Info: Received 25 March 2020; Review Completed 22 May 2020; Accepted 30 May 2020; Available online 15 June 2020

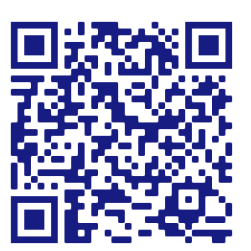

Cite this article as:

Bhat SA, Rather SA, Iqbal A, Qureshi HA, Islam N, Immunomodulators for Curtailing COVID-19: a Positive Approach, Journal of Drug Delivery and Therapeutics. 2020; 10(3-s):286-294 http://dx.doi.org/10.22270/jddt.v10i3-s.4085

*Address for Correspondence:

University of Kashmir, 190006, Srinagar, Jammu \&Kashmir, India

\section{INTRODUCTION}

SARS-CoV-2 is a single-stranded RNA virus belonging to the family Coronaviridae [1]. It is highly infectious, spreading swiftly from man to man which has not been previously recognized in humans [2]. The virus has spread in almost all the countries of the world and has created a global threat to the mankind. World Health Organization (WHO) on February 11,2020 named the infection as COVID-19 as an acronym for 'coronavirus disease-2019' and on March 11, 2020 declared the outbreak as pandemic [2,3]. COVID-19 can affect all the people without discrimination, however, older, immune compromised and people with health problems like diabetes, obesity, chronic respiratory illness and cardiovascular ailments are more susceptible $[1,4]$. The virus chiefly spread through droplet infection from infected person to healthy one by coughing, sneezing or with infected hands when touched to eyes, nose or mouth. $[1,2,4]$. Coronaviruses are said to have glycoproteins composed of two subunits, S1 and S2 which form the viral surface and in fact guide the host receptors [5]. Strong immune response in the host against the virus, labeled as cytokine storm, results in serious tissue damage. Interleukin- 6 produced by leukocytes is considered to be the protagonist of this whole storm [6]. The infection may begin with dry cough, tiredness, head ache, mild fever, and rarely diarrhea, sore throat, nasal congestion or running nose. In severe cases (approx. 14\% of cases) fever typically of high grade (104 $\mathrm{oF}$ ), breathlessness, pneumonia and severe acute respiratory syndrome may occur. A good percentage of people remain asymptomatic $[1,7]$. Diagnostic tests currently in use involve polymerase chain reaction, serological assay, and rapid antigen test. A chest X-ray or CT scan can be helpful for detecting pathological changes in the lungs [5,7]. So far no specific treatment or vaccine for novel coronavirus-2019 is there and the patients have to be managed only with symptomatic treatment. In case of breathlessness oxygen therapy is recommended and in case of respiratory failure mechanical ventilation is needed while as septic shock requires hemodynamic support $[1,7,8]$. Various antivirals and antimicrobials used in different countries to curtail the disease include Lopinavir/Ritonavir (400/100 mg 12 
hourly), Chloroquine (500 mg 12 hourly) and Hydoxychloroquine (200 mg 12 hourly). Some suggest human IgG1 monoclonal antibody, commonly used in rheumatoid arthritis treatment [1,7]. Having no specific treatment for the disease, prevention has the paramount importance to be safe. Moreover, social distancing, quarantine and isolation of suspected cases are the best tools for containing the disease [2,4]. Maintenance of proper hygiene, washing hands frequently with soap or alcohol (> $70 \%$ ) based sanitizers, and use of masks at public places have utmost importance. As of April 30, 2020 more than 33 lakh cases and about 234000 deaths have been reported throughout the globe. USA is the worst hit country till date where more than 60,000 mortalities have been recorded followed by Italy, Spain, France and UK [2]. The average mortality rate is about 3-4 percent [2]. In the current pandemic viral infection (COVID-19) it is clear that those with weak immune system are highly susceptible to this infection and its worst outcomes. In this regard immune enhancing herbs may definitely be helpful for the body to fight COVID-19 infection. Here we provide a review of some immune boosting herbs and their important features with preclinical and clinical evidences of their antiviral actions.

\section{IMMUNE MODULATING HERBS}

\section{Giloy (Gilu) (Tinospora cordifolia)}

Gilu in Unani and Guduchi in Ayurvedic systems of medicine have tremendous medicinal benefits. It has been used for centuries in all types of fevers, and for blood purifying, immune empowering, analgesic, and anti-inflammatory benefits. It is a remedy of choice for chronic cough, breathlessness, tuberculosis, leprosy, syphilis, and gonorrhea in Unani medicine. A dose of 10-20 gm is recommended in the form of decoct $[9,10]$. Substances isolated from tinospora cordifolia include, polysaccharides, phenolics, diterpenoid, steroids, and sesquiterpenoids [11]. Tinospora cordifolia hold free radical scavenging property and decrease the activities of superoxide dismutase and glutathione peroxidase in rat models $[12,13]$. Effects similar to that of indomethacin and nonsteroidal anti-inflammatory drugs have been found [14]. Tinospora cordifolia reduces histamine induced bronchospasm in various animal studies $[15,16]$. Vedavanthy et al. demonstrated antipyretic and Gupta et al. observed its antimicrobial effect $[17,18,19,20]$. One of compounds, 1, 4-alpha-D-glucan derived from Tinospora cordifolia has been found to activate macrophages, NFKB translocation and cytokine production, and hence activates the immune system [21,22]. Favorable effects of Tinospora cordifolia in HIV positive patients and Infectious bursal disease in young chicks were exposed when it was used with conventional antiviral treatment [23].

\section{Saffron (Zafran) (Crocus sativus)}

Saffron, one of the most valuable spices, is produced after processing dried stigmas of Crocus sativus [24]. In Unani system of medicine it is being used since ancient times as an anti-inflammatory, expectorant, brain tonic, and cardiotonic. As a medicine a dosage of 1-2 grams of saffron is recommended by Unani experts [9]. Saffron has 63\% sugar, $12 \%$ proteins, $5 \%$ fat, $5 \%$ minerals, $10 \%$ water and some fiber. Bioactive ingredients of saffron include safranol, crocin, and picrocrocin. In addition to these ingredients it contains about 150 volatile compounds [25]. Multiple in vitro and in vivo studies have revealed its potent anti-aging [26], anti-inflammatory [27], antioxidant [26], antimicrobial $[28,29]$, antiviral [30]and free radical scavenging properties. It also has cardioprotective, neuroprotective nephronprotective, hepatoprotective, and antiasthmatic properties
[31]. Saffron is a strong immune booster acting both on humoral and cellular immunity [32].

\section{Black cumin (Kalonji) (Nigella sativa)}

Also known as Kalonji, are seeds of a flowering plant belonging to family Ranunculaceae. It has bitter taste. Black cumin has immunomodulatory [33], anti-inflammatory [34], antibacterial [35], analagesic, antioxidant, anti-cancer, antidiabetic, antiasthmatic, bronchodilator, hepatoprotective, gastroprtective, and nephroprotective activities $[9,36]$. The dosage of black cumin as per Unai medicine, is 1$2 \mathrm{gm}$ [9]. In prophetic medicine it is recommended to be taken on daily basis for its tremendous benefits. The seeds of black cumin contain about $28,5 \%$ fats, $26.7 \%$ proteins, $24.9 \%$ carbohydrates, crude fiber and a good amount of minerals [37]. The important bioactive substances found in black cumin are; thymoquinone, dithymoquinone, p-cymene, alfa-pinene, thymohydroquinone, sesquiterpene, carvacrol, pentacyclic triterpene, terpineol, and saponins [37]. Antibacterial activity against staphylococcus aureus, Salmonella typhimurium, pseudoaeruginosa and H-pylori has been experimented [38,39]. Nigella shows significant antiviral activity against herpes simplex virus type-1 [40] Antiviral activity was also demonstrated by Salem et al. using murine cytomegovirus as a model in BALB/c mice [41]. Further studies have demonstrated nigella extract effective against hepatitis C virus, H9N2, HIV virus, etc. $[42,43,44]$

\section{Indian goose berry (Amla) (Emblica Officinalis Gaertn.)}

Alternately called as 'Amla', is sour in taste and is one of the richest sources of vitamin C. the fruit of amla is mainly used for the medicinal purposes usually dosage of about $10 \mathrm{gm}$. This wonder fruit has a wide range of activities and can treat number of ailments. It is used in common cold, fever, dyspepsia, hair growth, liver disorders etc. [9]. Amla contains ascorbic acid, iron, calcium and various bioactive compounds like gallic acid, ellagic acid, norsesquiterpenoids, gearaniin, and prodelphinidins. Many preclinical studies have revealed amla a potent antioxidant, anti-inflammatory, immune enhancer, free radical scavenger, antipyretic, antitussive, hematinic, hepatoprotective, neuroprotective and antcancer [45]. Because of its extreme immune empowering property it is believed to be effective against viral infections. It is effective in common cold, bronchitis, influenza and augments improvement in AIDS and cancer patients [46].

\section{Turmeric (Chob zard) (Curcuma longa)}

A rhizome which is yellow in color is a well-known spice and has tremendous medicinal benefits. According to Unani medicinal system it is used as phlegmagogue, antiinflammatory, analgesic, antipyretic, blood purifier, and has healing properties. The herb is utilized in the form of decoct or powder with a dosage of 1-3 gm [9]. Scientists have reported it to have antioxidant, immunemodulating, antiinflammatory, antimicrobial and anticancer activities [47]. The important ingredients of Curcuma longa are Curcumin, dihydrocurcumin, and hexahydrocurcumin. Some volatile componds like cinol, $\alpha$-phellandrene, borneol, zingiberine and different sesquiterpenes have been found in turmeric [48]. Curcumin has been observed to be extremely effective in acute respiratory distress syndrome, COPD's, acute lung injury and pulmonary fibrosis [49]. Turmeric suppresses TNF- $\alpha$ and inhibit NF- $\kappa B$, in this way acts as a potent antiinflammatory agent. [50]. Curcuma extract acts against various pathogenic bacteria including Streptococcus, Staphylococcus, Klebsella pneumoniae, Helicobacter pylori, Bacillus subtilis, Vibrio chlolera etc. [51,52,53,54]. Extreme 
potential of this herb has been observed against the viruses like H1N1, H6N1, respiratory syncytial virus, herpes simplex virus, parainfluenza virus type-3, coxsakievirus B3, Japanese encephalitis, hepatitis B virus, hepatitis C virus, human papillomavirus-16 and -18 [55,56,57,58,59,60,61]. It has also been found to inhibit HIV-1 long terminal repeatdirected gene expression [62].

\section{Licorice (Mulethi) (Glycyrrhiza glabra)}

According to Unani system of medicine it is hot and wet in temperament as per a standard temperament scale. Since ancient times it has been used for respiratory ailments as an expectorant, mucolytic, and phlegmagogue. It is also regarded as detoxicant, anti-inflammatory, anti-pyretic, diuretic, immune empowering, and a nerve stimulant. Licorice for medicinal purposes is used mostly in the form of decoct with a dosage of 3-7 gm [9]. Recent scientific studies have revealed it's potent anti-microbial, antioxidant, immune modulating, anti-viral, anti-inflammatory, and antitumor activities. A number of bioactive compounds have been isolated which are; glycyrrhizin, glabridin, 18-betaglycyrrhetinic acid, liquiritigenin, licochalcone $\mathrm{A}$ and licochalcone E, responsible for its broader activities [63]. Various in vitro and in vivo studies have demonstrated the action of glycyrrhiza extract against hepatitis $\mathrm{C}$ virus, coxackievirus B3, H5N1 influenza A virus, H3N2 influenza virus, human respiratory syncytial virus, coxackievirus A16 and enterovirus 71 etc. $[64,65,66,67,68,69,70,71]$. Hong et al. have shown immunomodulatory and antioxidant effects of licorice in mice [72] while as Wang et al. have demonstrated its anti-inflammatory effect [73]. A study in the mouse model revealed glycyrrhizin ameliorates histopathologic changes in asthmatic lung [74]. It has also been revealed to inhibit the replication of highly fatal SARS virus [75].

\section{Hedge mustard (Khaksi) (Sisymbrium officinale)}

In Unani system of medicine hedge mustard is famous with the name 'Khaksi'. Its seeds are used for medicinal purposes both internally and externally for different ailments. It is considered to be the drug of choice for all types of fevers, measles and chicken pox in Unani system of medicine. it has also been used for cough, expectoration of accumulated phlegm in the chest, cholera, tuberculosis, in traditional medicinal systems. The recommended dosage is 5-7 gm in the form of decoct [9]. Multiple bioactive and volatile compounds like isopropyl-isothiocyanate, butylisothiocyanate, phenylethyl alcohol, eugenol etc.ave been isolated from these seeds. They have a wide range of antimicrobial activity against gram positive and ampicillin resistant gram negative bacteria [76]. Sotto et al showed its strong action against leukotriene and histamine and a potent antimutagenic activity in e-coli and salmonella typhimurium [77].

\section{Neem (Azadirachta indica)}

It is a well-known antiseptic, blood purifier, antimicrobial, analgesic, antipyretic and anti-inflammatory action bearing plant in Indian system of medicine. Mostly bark and leaves are used for medicinal purposes. The recommended dosage is 6-10 gm in the form of decoct [9]. Different compounds isolated from this herb includes; nimbin, nimbidin, nimbolide, limonoids, $\beta$-sistosterol and quercitin [78]. Scientific studies have proven its antioxidant [79], antiinflammatory, immune modulatory [80], antibacterial [81], antifungal [82], antipyretic and anticancer activities [83]. Besides having immune modulatory function it has been found in vitro studies that it inhibit the viral replication and is a potent virucidal for coxsackieviruses, herpes simplex virus type-1, etc. $[84,85]$. A compound from the extract of neem leaves called as 'hyperoside', possesses potential effect against influenza strains besides its free radicle scavenging property [86].

\section{Ginger (Adrak) (Zingiber officinale)}

A rhizome, brown in color and bitter in taste, is having hot and dry temperament according to Greco-Arab medicine. It is commonly used in traditional medicine as an appetizer and general tonic in a dosage of 1-1.5 gm [9]. The rhizome has been used for centuries in the treatment of anorexia, flatulence, high blood pressure, arthritis and common cold. It contains many bioactive ingredients like gingerol, zingiberine, shogaol, gingerdione, hexahydrocurcumin, paradol and gingerenone A [87]. According to newer researches, ginger is having very high levels of antioxidants that help reduce oxidative stress and inhibit superoxide production. Extract of dried ginger possesses powerful antiinflammatory and analgesic activities [88]. It has also been reported having better effect against swine flu (H1N1), and human respiratory syncytial virus in human respiratory tract cell lines [89.90]. Denyer et al. isolated antirhinoviral sesquiterpenes from ginger about two decades ago [91]. Ginger provides brochodilatory effect, prevents severe damage to the lungs due to inflammation and ameliorates allergic asthma [92,93,94]. In addition to this, multiple studies have been performed showing its anti-diabetic, cardioprotective and anti-cancerous effects as well.

\section{Cinnamon (Darchini) (Cinnamomum zeylanicum)}

A good smelling, reddish brown bark of a plant belongs to Lauraceae family. It is commonly used as spice and is said to be hot and dry in temperament by Greco-Arab texts. According to these texts, it has been used for centuries in treating respiratory ailments like cough and asthma besides having antiseptic, cardiotonic, aphrodisiac and phlegmagogue actions. It can be used in powder or decoct form in a dosage of 1-2 gm [9]. In addition to its antiinflammatory, antioxidant and antimicrobial properties researchers have found this herb effective in diabetes, Alzheimer's disease, ischemic heart diseases, dyslipidemia, hypertension and gastric cancer. The active ingredients present in cinnamon are cinnamic acid, cinnamaldehyde, cinnamate and various essential oils like eugenol, transcinnamaldehyde, cinnamyl acetate, caryophyllene oxide, Lborneol, E-nerilidol, b-caryophyllene, $\alpha$-thugene, $\alpha$ cubebene, $\alpha$-terpinol, and terpinolene [95]. Schink et al., Han $X$ et al. and Gunawardena et al. have separately demonstrated the anti-inflammatory activity of cinnamon extract $[96,97,98]$. Extensive studies reveal a potential antimicrobial activity of cinnamon. The extract nanoparticles from the bark were proven to have antiviral effect, inhibiting the activity of H7N3 influenza A virus in Vero cells [99]. In vitro study by Brochot et al. have depicted that cinnamon along with some other medicines could be highly effective in acute and chronic human infections either bacterial, viral or fungal [100]. Procyanidin type A, a cinnamon derived compound, inhibits hepatitis $C$ virus cell entry as studied by Catherine Fauvelle and associates [101]. This proves the potential of cinnamon against the dreadful viruses.

\section{Pepper Mint (Pudina) (Mentha piperita)}

A well-known aromatic herb leaves of which in both fresh and dried form are used for cooking and medicinal purposes. Greco-Arab medicinal system primarily recommends it for various diseases of gastro-intestinal system like dyspepsia, for asthma, breathlessness and as diuretic. It is said to be hot and dry in temperament and is given in the form of decoct using a dosage of 3-5 gm [9]. Various bioactive constituents present in it include phenollic components and flavonoids 
while as menthol and menthone are its main volatile components. Potent antioxidant, immunomodulatory, antiviral, antimicrobial, antitumor, analgesic and antiallergenic properties of mint have gained the attention of medical researchers [102]. In vitro study of peppermint oil shows virucidal effect on herpes simplex virus type 1 and type 2 [103]. An in vitro study in China by YuXian Li et al. has shown a significant antiviral effect of pepper mint extract when compared with ribavirin indicating a better future antiviral plant resource. In the same study high antioxidant property was noted and significant reduction in tumor necrosis factor- $\alpha$, nitric oxide, interleukin- 6 , and prostaglandin E2 indicates its strong anti-inflammatory effect [104].

\section{Garlic (Lehsun) (Allium sativum)}

Garlic, a compound tunicate bulb belongs to Lillaceae family, is hot and dry in temperament as per Greco-Arab system of medicine [9]. Avicenna in his book Alqanūn fit tib (Canon of medicine) has mentioned that garlic is useful in chronic cough, arthritis and constipation [105]. Garlic has also been mentioned to protect from epidemic diseases. It can be eaten in raw form individually or with other medicines usually in a dosage of 2-3 gm [9]. Garlic has many active ingredients including alliin, allicin, ajoene, vinyldithin, S-allylcycsteine and diallyl sulphides [106]. A plethora of studies revealed garlic to have antioxidant, anti-inflammatory, immune modulating, antibiotic, bacteriostatic, antifungal, antiviral, antihelminthic, antithrombic, hypotensive, hypoglycemic, and hypocholestrolemic properties. Extract of garlic was found to have antiviral action against influenza B, herpes simplex and coxsackieviruses [106,107]. Virucidal effect was also seen against human rhinovirus-2, parainfluenza virus-3, HSV-1, HSV- 2 and vesicular stomatitis virus during in vitro study by Weber et al. more than two decades ago. In his study ajoene was observed having the highest virucidal activity followed by allicin, allyl-methyl thiosulphinate and lastly methyl-allyl thiosulphinate [108]. Later demonstrations of its action against cytomegalovirus [109] and infectious bronchitis virus are also worth consideration [110]. Being a good antimicrobial, it has depicted significant effect against staphylococcus aureus, E. coli, campylobacter jejuni, streptococcus mutans, lactobacillus acidophilus and salmonella species $[111,112,113,114,115]$. In an interesting study aged garlic was found to have more potent antioxidant and antimicrobial activities than fresh one [116]. Kang et al. explored antioxidant and reactive oxygen species scavenging property of garlic saponins while as Naji et al. demonstrated hepatoprotective and antioxidant property of single clove garlic in rabbits $[117,118]$. Keiss et al. have investigated garlic modulates cytokine expression in lipopolysacharide activated human blood and inhibit NF- $\mathrm{KB}$ from which its immune modulatory effect is evident [119]. It has also been observed to activate macrophages and promote immunoglobulins [120]. Garlic extract reduces migration of polymorphonuclear cells through endothelial cell layers [121]. It inhibits production of nitric oxide and prostaglandin-E2, suppresses inducible form of nitric oxide synthase and COX-2 expression, and decreases the production of inflammatory cytokines like TNF- $\alpha$, interleukin 6 and interferon $\gamma[122,123]$. In particular to respiratory system, it was investigated to improve lung function in smokers, [124] and reduce tracheal exudates in horses [125]. Ellizabeth and others investigated its significance in common cold while as Hsieh et al and Zare et al demonstrated significant efficacy of garlic extract in inflammatory and asthma like condition of lungs $[126,127,128]$.

\section{Black pepper (Siya mirch) (Piper nigrum)}

The 'king of spices' widely used as a flavoring agent and taste enhancer of various dishes. Knowing about its features, it is small, rounded and black fruit of a plant somewhat bitter in taste and zesty nature. In Greco-Arab medicine it is considered to have hot and dry temperament and is being used for its analgesic, anti-inflammatory, phlegmagogue, expectorant, appetizer, anti-flatulent, aphrodisiac, anti-venom, cardioprotective, neuroprotective, and general health boosting actions for centuries [9]. It is said to be effective in fevers, breathlessness, asthma, and other respiratory diseases. The recommended dosage of black pepper is $0.4-1.25 \mathrm{gm}$ in the form of powder or decoct [9]. Various bioactive components derived from black pepper include piperine, piperic acid, piperamide, piperlonguminine, piperolein-B, pellitorine, piperitine, eugenol and kusonokinin in addition to some volatile oils. Multiple in-vitro and in-vivo studies have been carried out to prove antioxidant, anti-inflammatory and antimicrobial properties besides other benefits particularly its marked bio-enhancing ability $[129,130]$. The significant antioxidant and free radical scavenging property of its extract was experimented in rats by Ilhami Gulcin and in vitro by Sing et at. [131,132]. Analgesic and anti-inflammatory effect of piper nigrum was evaluated by Tasleem et al., Bang JS et al., etc. $[133,134]$. Zou L et al. studied antimicrobial activity of chloroform extract of black pepper against $\mathrm{E}$ coli and staphylococcus aureus [135]. Similarly Tang $\mathrm{H}$ et al proved its significant efficacy against Listeria monocytogenes and gram negative salmonella typhimurium bacilli [136]. Christina Elizabeth and associates demonstrated antiviral and anti-proliferative action of piperamide derived from black pepper [137].

\section{Winter cherry (Asgandh) (Withania somnifera)}

In india it is called 'Ashwagandha' and has unquestionable medicinal properties used traditionally for thousands of years. The root of this herb is mainly used for medicinal purposes in a dosage of 3-5 gm. It is mostly used as a general body tonic, nerve tonic, aphrodisiac, anti-inflammatory, antiarthitic and antivenom medicine [9]. Various clinical trials have evaluated the efficacy of ashwagandha in inflammation, anxiety, neurologic and cognitive disorders. Ashwagandha contains alkaloids, sterols, saponins, aminoacids and polysaharides. Among alkaloids, ashwagandhine, isopelletierine, cuseohygrine, trpine, anaferine etc. have been isolated. The multiple number of sterols derived from this herb includes, withaferins, withasomniferin A, withasomidienone, withanolides, and withanone. Sitoindisides (VII, VIII, IX and X) and withaferin A, derived from ashwagandha have shown antidepressant properties [138]. It has been found to have a potent immunomodulatory function [139]. The adaptogenic and antisress properties of this herb has been proved in multiple animal studies. It has also promising anti-inflammatory, antibacterial, immune enhancing and antitumor properties [140]. Ziauddin et al in mice model observed effect of ashwagandha after inducing myelosuppression by cyclophosphamide, azathioprin and prednisolone separately. They studied that ashwagandha prevent myelosuppression by all the three drugs, revealing the immune modulating potential of the herb [141]. A molecular docking study by Zhi Cai et al. illustrated that the binding affinity of withaferin A, a constituent of ashwagandha, towards neuraminidase is quit high and inhibit neuraminidase of H1N1 influenza virus potently [142]. Furthermore in vitro studies have also shown it to be effective against infectious bursal disease virus and many other viruses due to its immune enhancing property. 


\section{Cinchona bark (Chal-i-konain) (Cinchona officinalis)}

Cinchona bark (Chal-i-konain) is an age old recommended medicine for fevers, inflammations, and other ailments in traditional medicinal system. It is obtained from a variety of cinchona species. Centuries ago it was used as a drug of choice for malaria by the South American indigenous population. Later it became a primary remedy for malaria throughout the world. Many bioactive compounds derived from this bark are those of chinoline derivatives (cinchonine, quinine, cinchonidine, and quinidine). Others are their dihydro- derivatives [143]. Cinkona is also used for common cold, influenza, leg cramps etc. Interestingly its use has been extended to arrythmias, systemic lupus erythematosus and arthritis in this scientific era. From this fact it is thought to posses anti-inflammatory and immune modulating functions [144]. Recently antimalarial drugs chloroquine and hydroxychloroquine have been found effective against SARSCoV-2 to some extent as per reports of WHO.

Studies have shown that herbal derivatives; sesquiterpenoids, diterpenoids, triterpenoids, curcumin and lignoids inhibit SARS-CoV [145]. In a molecular docking study several herbal medicinal compounds like glucoside, dimethoxycurcumin, curcumin, catechin and epicatechin gallate are observed to have potent inhibitory activity against COVID-19 [146]. A case report from Wuhan city in China confirms that herbal medicine along with western medicine proved wonder when no improvement was observed with other antibiotics and steroids [147]. Authentic reports revealed the use of traditional herbs for the past coronavirus epidemics and the current COVID-19 in China which proved highly beneficial [148]. The fruitful results achieved from the herbs, encourages further research to evaluate their use in controlling COVID-19 catastrophe.

\section{CONCLUSION}

SARS-Co-2 (COVID-19) disease is a highly fatal disease, currently a challenge for whole medical world as well as for leaders throughout the globe. No specific vaccine or treatment has been developed till date and supportive treatment is the only tool for disease management. Arbitrary studies of some drugs are being performed, including some specific trials going on, in different countries. At this juncture when physique and immune system of a person is tested by the virus and only those having strong immunity can thrive in this fight. In nature we have a treasury of herbal medicines which mankind is using since time immemorial. Although, a complete scientific validation of these herbs have not been evaluated, but traditional medicinal systems have been proved successful from time to time in different diseases. Viral epidemics were also present in the past and recent past and we have learnt from these experiences that herbal medicines have proven beneficial. The above mentioned herbs boost the immune system of a person and may help to fight against the virus by his own defensive system. In addition to this, they have proven antiinflammatory, antioxidant, antimicrobial and antiviral effects in different studies. So it is a high time to adopt the use of herbal medicines as primary or adjuvant therapy for prevention and cure of COVID-19 infection.

\section{ABBREVIATIONS}

NFK-B - Nuclear factor kappa-light-chain-enhancer of activated $B$ cells

SARS-CoV - Severe acute respiratory syndrome-related coronavirus

\section{CONFLICT OF INTEREST}

The authors have no conflict of interest.

\section{REFERENCES}

1. Guo YR, Cao QD, Hong ZS, et al. The origin, transmission and clinical therapies on coronavorus disease 2019 (COVID-19) outbreak-an update on the status. Mil Med Res. 2020; 7(1):11. doi:10.1186/s40779-020-00240-0

2. World Health Organization. "Q\&A on coronaviruses" (https://www.who.int/news-room/q-a-detail/q-

acoronaviruses). April 23, 2020. Retrieved April 23, 2020.

3. World Health Organization (WHO). "Naming the coronavirus disease (COVID-19) and the virus that causes it."

(https://www.who.int/emergencies/diseases/novelcoronavir us2019/technicalguidance/naming-the-coronavirus-disease(covid-2019)-and-the-virus-that-causes-it). Archived (https://web.archive.org/web/20200228035651/https://w ww.who.int/emergencies/dise ases/nov el-coronavirus2019/technical-guidance/naming-the-coronavirusdisease(covid-2019)-and-the -virus-that-causes-it) from the original on 28 February 2020. Retrieved 28 February 2020.

4. Anonymous. "Coronavirus Disease 2019 (COVID-19) Transmission" (https://www.cdc.gov/coronavirus/201 9ncov/prepare/transmission.html). Centers for Disease Control and Prevention. Updated on April 13, 2020. Retrieved April 232020.

5. Chan JF, Kok KH, Zhu Z, Chu H, To KK, Yuan S, Yuen KY. Genomic characterization of the 2019 novel humanpathogenic coronavirus isolated from a patient with atypical pneumonia after visiting Wuhan. Emerg Microbes Infect. 2020; 9(1):221-236.

6. Song W, Gui M, Wang X, Xiang Y. Cryo-EM structure of the SARS coronavirus spike glycoprotein in complex with its host cell receptor ACE2. PLoS Pathog. 2018; 14(8):e1007236.

7. Cascella M, Rajnik M, Cuomo A, et al. features, evaluation and treatment coronavirus (COVID-19) [updated 2020 Mar 20]. In: Statpearls [internet]. Treasure Island (FL): Statpearls Publishing. 2020 Jan.

8. $\mathrm{Wu} \mathrm{Z}, \mathrm{McGoogan}$ JM. Characteristics of and important lessons from the coronavirus disease 2019 (COVID-19) outbreak in China: Summary of a report of 72314 cases from the Chinese centre for disease control and prevention. JAMA. 2020. doi:101001/jama.2020.2648

9. Kabir-ud-din M. Makhzanul Mufradāt. New Delhi: Ejaz publishing house; YNM. pp. 55,75,76,263,312, 317,460,461, $550,595,596$.

10. Upadhyay AK, Kumar K, Kumar A, Mishra HS. Tinospora cordifolia (Wild.) Hook.f. and Thoms. (Guduchi)- Validation of the Ayurvedic pharmacology through experimental and clinical studies. Int J Ayurveda Res. 2010; 1(2):112-121. doi:10.4103/0974-7788.64405

11. Khosa RL, Prasad S. Pharmacognostical studies on Guduchi (Tinospora cordifolia Miers) J Res Ind Med. 1971;6:261-9. [Google Scholar]

12. Badar VA, Thawani VR, Wakode PT, Shrivastava MP, Gharpure KJ, Hingorani LL, et al. Efficacy of Tinospora cordifolia in allergic rhinitis. J Ethnopharmacol. 2005; 96:445-9. [PubMed]

13. Nayampalli S, Ainapure SS, Nadkarni PM. Study of antiallergic acid Bronchodilator effects of Tinospora cordifolia. Indian $J$ Pharmacol. 1982;14:64-6. [Google Scholar]

14. Nayampalli SS, Desai NK, Ainapure SS. Anti-allergic properties of Tinospora cordifolia in animal models. Indian J Pharmacol. 1986; 18:250-2. [Google Scholar]

15. Rawal AK, Muddeshwar MG, Biswas SK. Rubia cordifolia, Fagonia cretica linn and Tinospora cordifolia exert neuroprotection by modulating the antioxidant system in rat hippocampal slices subjected to oxygen glucose deprivation. BMC Complement Altern Med. 2004; 13(4):11. [PubMed]

16. Prince PS, Kamalakkannan N, Menon VP. Restoration of antioxidants by ethanolic Tinospora cordifolia in alloxaninduced diabetic Wistar rats. Acta Pol Pharm. 2004; 61:283-7. [PubMed]

17. Vedavathy S, Rao KN. Antipyretic activity of six indigenous medicinal plants of Tirumala Hilla, Andhra Pradesh, India. $J$ Ethnopharmacol. 1991; 33:193-6. [PubMed] 
18. Ikram M, Khattak SG, Gilani SN. Antipyretic studies on some indigenous Pakistani medicinal plants: II. J Ethnopharmacol. 1987; 19:185-92. [PubMed]

19. Jeyachandran R, Xavier TF, Anand SP. Anti-bacterial activity of stem extracts of Tinospora cordifolia (willd). Ancient Science life. 2003; 23:40-4. [PubMed]

20. Gupta KC, Viswanathan R. Antituberculous substances from plants. Antibiot Chemother. 1956; 6:194-5. [PubMed]

21. Nagarkatti DS, Rege NN, Desai NK, Dahanukar SA. Modulation of Kupffer cell activity by Tinospora cordifolia in liver damage. J Postgrad Med. 1994; 40:65-7. [PubMed]

22. Nair PK, Rodriguez S, Ramachandran R, Alamo A, Melnick SJ, Escalon E, et al. Immune stimulating properties of a novel polysaccharide from the medicinal plant Tinospora cordifolia. Int Immunopharmacol. 2004; 4:1645-59. [PubMed]

23. Sachan S, Dhama K, Latheef SK, Samad HA, Mariappan AK, Manuswamy $\mathrm{P}$, et al. Immunomodulatory potential of Tinospora cordifolia and CpG ODN (TLR21 Agonist) against the very virulent infectious Bursal disease virus in SPF Chicks. Vaccines 2019; 7(3):106. doi:10.3390/vaccines7030106

24. Gohari AR, Saeidnia S, Mahmoodabadi MK. An overview on saffron, phytochemicals, and medicinal properties. Pharmacogn Rev. 2013; 7(13):61-66. doi:10.4103/09737847.112850

25. Rezaee R, Hosseinzadeh H. Safranal: from an aromatic natural product to a rewarding pharmacological agent. Iran J Basic Med Sci. 2013; 16:12-26. [PubMed]

26. Assimopoulou AN, Sinakos Z, Papageorgiou VP. Radical scavenging activity of Crocus sativus $\mathrm{L}$ extract and its bioactive constituents. Phytother Res. 2005; 19:997-1000. [PubMed]

27. Moallem SA, Hosseinzadeh H, Farahi S. A study of acute and chronic anti-nociceptive and anti-inflammatory effects of thiamine in mice. Iran Biomed J. 2008; 12:173-178. [PubMed]

28. Eslami M, Bayat M, Mozaffari Nejad AS, Sabokbar A, Anvar AA Effect of polymer/nanosilver composite packaging on longterm microbiological status of Iranian saffron (Crocus sativus L) Saudi J Biol Sci. 2016; 23:341-347. [PubMed]

29. Liu M, Amini A, Ahmad Z. Safranal and its analogs inhibit Escherichia coli ATP synthase and cell growth. Int J Biol Macromol. 2017; 95:145-152. [PubMed]

30. Soleymani S, Zabihollahi R, Shahbazi S, Bolhassani A. Antiviral Effects of Saffron and its Major Ingredients. Current Drug Delivery (2018) 15: 698.

https://doi.org/10.2174/1567201814666171129210654. [PubMed]

31. Razavi BM, Hosseinzadeh H. Saffron as an antidote or a protective agent against natural or chemical toxicities. Daru. 2015; 23:31. [PubMed]

32. Zirak MZ, Rezaee SA, Karimi G, and Hosseinzadeh H. Immunoregulatory and anti-inflammatory properties of Crocus sativus (Saffron) and its main active constituents: A review. Iran J Basic Med Sci. 2019 Apr; 22(4): 334-344. [PubMed]

33. Majdalawieh AF, Hmaidan R, Carr RI. Nigella sativa modulates splenocyte proliferation, Th1/Th2 cytokine profile, macrophage function and NK anti-tumor activity. J Ethnopharmacol. 2010; 131(2):268-275.

34. Chehl N, Chipitsyna G, Gong Q, Yeo CJ, Arafat HA. Antiinflammatory effects of the Nigella sativa seed extract, thymoquinone, in pancreatic cancer cells. HPB (Oxford) 2009; 11(5):373-381.

35. Halawani E. Antibacterial activity of thymo-quinone and thymohydroquinone of Nigella sativa L. and their interaction with some antibiotics. Adv Biol Res. 2009; 148-152.

36. Ahmad A, Husain A, Mujeeb M, et al. A review on therapeutic potential of Nigella sativa: A miracle herb. Asian Pac J Trop Biomed. 2013;3(5):337-352. doi:10.1016/S22211691(13)60075-1

37. Al-Jassir MS. Chemical composition and microflora of black cumin (Nigella sativa L.) seeds growing in Saudi Arabia. Food Chem. 1992; 45:239-242.

38. Bakathir HA, Abbas NA. Detection of the antibacterial effect of Nigella sativa ground seeds with water. Afr J Tradit Compl Altern Med. 2011; 8(2):159-164.

39. Salem EM, Yar T, Bamosa AO, Al-Quorain A, Yasawy MI, Alsulaiman RM, et al. et al. Comparative study of Nigella sativa and triple therapy in eradication of Helicobacter Pylori in patients with non-ulcer dyspepsia. Saudi J Gastroenterol. 2010; 16(3):207-214.

40. Ogawa K, Nakamura S, Hosokawa K, Ishimaru H, Saito N, Ryu $\mathrm{K}$, et al. New diterpenes from Nigella damascena seeds and their antiviral activities against herpes simplex virus type-1. J Nat Med. 2018; 72(2):439-447. doi: 10.1007/s11418-017-1166-6. Epub 2017 Dec 29.

41. Salem ML, Hossain MS.Protective effect of black seed oil from Nigella sativa against murine cytomegalovirus infection. Int J Immunopharmacol. 2000; 22(9):729-740.

doi:10.1016/s0192-0561(00)00036-9

42. Onifade AA, Jewell AP, Adedeji WA. Nigella satva concoction induced sustained seroreversion in HIV patient. Afric J Trad Complement AlternatvMed. 2013; 10:332-5.

43. Oyero OG, Toyama M, Mitsuhiro N, Onifade AA, Hidaka A, Okamoto $M$, et al. selective inhibition of hepatitis $C$ virus replication by alpha-zam, a nigella sativa seed formulation. Afr J Tradit Complement Altern Med. 2016; 13:144-8.

44. Umar S, Munir MT, Subhan S, Azam T, Nisa Q, Khan MI, et al. protective and antiviral property of Nigella sativa against avian influenza (H9N2) in turkeys. J Saudi Soc Agric Sci. 2016; doi:10.1016/j.jssas.2016.09.004

45. Baliga MS, Dsouza JJ. Amla (Emblica officinalis Gaertn), a wonder berry in the treatment and prevention of cancer. Eur J Cancer Prev. 2011; 20(3):225-239.

46. Khare CP. Indian medicinal plants, An Illustrated Dictionary. New York: Springer Science + business media, LLC; 2007: pp. 238, 239.

47. Hewlings SJ, Kalman DS. Curcumin: A review of its effects on human health. Foods. 2017; 6(10): 92.

48. Prasad S, Aggarwal BB. Turmeric, the golden spice: From traditional medicine to modern medicine. In: Benzie IFF Wachtel-Galor S, editors. Herbal medicine: Biomolecular and Clinical aspects. $2^{\text {nd }}$ ed. Boca Raton (FL): CRC Press/Taylor and Francis; 2011. Ch.13.

49. Lelli D, Sahebkar A, Johnston TP, Pedone C. Curcumin use in pulmonary diseases: State of the art and future perspectives. Pharmacol Res. 2017; 115:133-148. [PubMed]

50. Shakibaei M, Jhon T, Schulze-Tanzil G, Lehmann I, Mobasheri A. Suppression of NF- $\kappa$ B activation by curcumin leads to inhibition of expression of cyclo-oxygenase-2 and matrix metalloproteinase-9 in human articular chondrocytes: implications for the treatment of osteoarthritis. Biochem Pharmacol. 2007. [PubMed]

51. Niamsa N, Sittiwet C. Antimicrobial activity of Curcuma longa aqueous extract. Journal of Pharmacology and Toxicology. 2009; 4(4):173-177. [PubMed]

52. Ungphaiboon S, Supavita T, Singchangchai P, Sungkarak S, Rattanasuwan P, Itharat A. Study on antioxidant and antimicrobial activities of turmeric clear liquid soap for wound treatment of HIV patients. Songklanakarin Journal of Science and Technology. 2005; 27(2):269-578. [PubMed]

53. Lawhavinit O-A, Kongkathip N, Kongkathip B. Antimicrobial activity of curcuminoids from Curcuma longa L. on pathogenic bacteria of shrimp and chicken. Kasetsart Journal-Natural Science. 2010; 44(3):364-371. [PubMed]

54. Hosny IM, El Kholy WI, Murad HA, El Dairouty RK. Antimicrobial activity of Curcumin upon pathogenic microorganisms during manufacture and storage of a novel style cheese 'Karishcum'. Journal of American Science. 2011; 7:611-618. [PubMed]

55. De R, Kundu P, Swarnakar S, et al. Antimicrobial activity of curcumin against helicobacter pylori isolates from India and during infections in mice. Antimicrobial Agents and Chemotherapy. 2009; 53(4):1592-1597. [PubMed]

56. Singh RK, Rai D, Yadav D, Bhargava A, Balzarini J, De Clercq E. Synthesis, antibacterial and antiviral properties of curcumin bioconjugates bearing dipeptide, fatty acids and folic acid. European Journal of Medicinal Chemistry. 2010; 45(3):10781086. [PubMed]

57. Chen D-Y, Shien J-H, Tiley L, et al. Curcumin inhibits influenza virus infection and haemagglutination activity. Food Chemistry. 2010; 119(4):1346-1351. [Google Scholar]

58. Divya CS, Pillai MR. Antitumor action of curcumin in human papillomavirus associated cells involves downregulation of viral oncogenes, prevention of NFkB and AP-1 translocation, 
and modulation of apoptosis. Molecular Carcinogenesis. 2006;45(5):320-332. [PubMed]

59. Si X, Wang Y, Wong J, Zhang J, McManus BM, Luo $\mathrm{H}$. Dysregulation of the ubiquitin-proteasome system by curcumin suppresses coxsackievirus B3 replication. Journal of Virology. 2007; 81(7):3142-3150. [PubMed]

60. Kim HJ, Yoo HS, Kim JC, et al. Antiviral effect of Curcuma longa Linn extract against hepatitis B virus replication. Journal of Ethnopharmacology. 2009; 124(2):189-196. [PubMed]

61. Kim K, Kim KH, Kim HY, Cho HK, Sakamoto N, Cheong J. Curcumin inhibits hepatitis $\mathrm{C}$ virus replication via suppressing the Akt-SREBP-1 pathway. FEBS Letters. 2010; 584(4):707712. [PubMed]

62. Li CJ, Zhang LJ, Dezube BJ, Crumpacker CS, Pardee AB. Three inhibitors of type 1 human immunodeficiency virus long terminal repeat-directed gene expression and virus replication. Proceedings of the National Academy of Sciences of the United States of America. 1993; 90(5):1839-1842. [PubMed]

63. Wang L, Yang R, Yuan B, Liu Y, Liu C. The antiviral and antimicrobial activities of licorice, a widely used Chinese herb. Acta Pharm Sin B. 2015; 5(4):310-315. [PubMed]

64. Matsumoto Y, Matsuura T, Aoyagi H, Matsuda M, Hmwe S.S, Date T. Antiviral activity of glycyrrhizin against hepatitis $\mathrm{C}$ virus in vitro. PLoS one. 2013; 8:e68992. [PubMed]

65. Ashfaq U.A, Masoud M.S, Nawaz Z, Riazuddin S. Glycyrrhizin as antiviral agent against hepatitis C virus. J Transl Med. 2011; 9:112. [PubMed]

66. Zhang H.C, Song Y.X, Zhang Z.C. Glycyrrhizin administration ameliorates coxsakievirus B3-induced myocarditis in mice. Am J Med Sci. 2012; 344:206-210. [PubMed]

67. Michaelis M, Geiler J, Naczk P, Sithisarn P, Leutz A, Doerr HW, et al. Glycyrrhizin exerts antioxidative effects in H5N1 influenza A virus replication and proinflammatory gene expression. PLoS one. 2011; 6(5):e19705. doi:10.1371/journal.pone.0019705.

68. Michaelis M, Geiler J, Naczk P, et al. Glycyrrhizin inhibits highly pathogenic H5N1 influenza A virus-induced proinflammatory cytokine and chemokine expression in human macrophages. Med Microbiol Immunol. 2010; 199(4):291-297. [PubMed]

69. Smirnov V.S, Zarubaev V.V, Anfimov P.M, Shtro A.A. Effect of a combination of glutamyl-tryptophan and glycyrrhizic acid on the course of acute infection caused by influenza (H3H2) virus in mice. Vopr Virusol. 2012; 57:23-27. [PubMed]

70. Yeh C.F, Wang K.C, Chiang L.C, Shieh D.E, Yen M.H, Chang J.S. Water extract of licorice had antiviral activity against human respiratory syncytial virus in human respiratory tract cell lines. J Ethnopharmacol. 2013; 148:466-473. [PubMed]

71. Wang J.J, Chen X.Q, Wang W, Zhang Y.T, Yang Z.Y, Jin Y. Glycyrrhizic acid as the antiviral component of Glycyrrhiza uralensis Fisch. against coxsackievirus A16 and enterovirus 71 of hand foot and mouth disease. J Ethnopharmacol. 2013; 147:114-121. [PubMed]

72. Hong Y.K, Wu H.T, Ma T, Liu W.J, He X.J. Effects of Glycyrrhiza glabra polysaccharides on immune and antioxidant activities in high-fat mice. Int $J$ Biol Macromol. 2009; 45:61-64. [PubMed]

73. Wang J.H, Kwas $\mathrm{C}, \mathrm{Wu}$ L. Intercellular adhesion molecule 1 (ICAM-1), but not ICAM-2 and -3 , is important for dendritic cell-mediated human immunodeficiency virus type 1 transmission. J Virol. 2009; 83:4195-4204. [PubMed]

74. Hocaoglu AB, Karaman O, Erge DO, Erbil G, et al. Glycyrrhizin and long-term histopathologic changes in a murine model of asthma. Curr Ther Res Clin Exp. 2011; 72(6):250-261. doi:10.1016/j.curtheres.2011.11.002

75. Cinatl J, Morgenstern B, Bauer G, Chandra P, Rabenau H, Doerr HW. Glycyrrhizin, an active component of licoriceroots, and replication of SARS-associated coronavirus. Lancet. 2003; 361(9372):2045-2046. doi:10.1016/s0140-6736(03)13615-x

76. Blazevic I, Radonic A, Mastelic J, Zekic M, Skocibusic M, Maravic A. Hedge mustard (Sisymbrium officinale): chemical diversity of volatiles and their antimicrobial activity. Chem. $\begin{array}{lll}\text { Biodivers. 2010; (8):2023-2034. } & \end{array}$ doi:10.1002/cbdv.200900234

77. Di Sotto A, Vitalone A, Nicoletti M, Piccin A, Mazzanti G. Pharmacological and phytochemical study on a sisymbrium officinale scop. Extract. J Ethnopharmacol. 2010; 127(3):731736. doi:10.1016/j.jep.2009.12.001

78. Mohammad A. Alzohairy. Therapeutics Role of Azadirachta indica (Neem) and their active constituents in diseases prevention and treatment. Evid Based Complement Alternat Med. 2016; 2016: 7382506. doi:10.1155/2016/7382506

79. Sultana B., Anwar F., Przybylski R. Antioxidant activity of phenolic components present in barks of Azadirachta indica, Terminalia arjuna, Acacia nilotica, and Eugenia jambolana Lam. trees. Food Chemistry. 2007; 104(3):1106-1114. doi: 10.1016/j.foodchem.2007.01.019.

80. Biswas K., Chattopadhyay I., Banerjee R. K., Bandyopadhyay U. Biological activities and medicinal properties of neem (Azadirachta indica) Current Science. 2002; 82(11):13361345.

81. Singh N., Sastry M. S. Antimicrobial activity of Neem oil. Indian Journal of Pharmacology. 1997; 13:102-106. [Google Scholar]

82. Kher A., Chaurasia S. C. Antifungal activity of essential oils of three medical plants. Indian Drugs. 1997; 15:41-42. [Google Scholar]

83. Paul R., Prasad M., Sah N. K. Anticancer biology of Azadirachta indica L (neem): a mini review. Cancer Biology and Therapy. 2011;12(6):467-476. doi: 10.4161/cbt.12.6.16850. [PubMed]

84. Badam L. Joshi SP, Bedekar SS. In vitro antiviral activity of neem (Azadirachta indica. A. Juss) leaf extract against group B coxsackieviruses. J Commum Dis. 1993; 31(2):79-90.

85. Tiwari V, Darmani NA, Yue BY, Shukla D. In vitro antiviral activity of neem (Azadirachta indica L.) bark extract against herpes simplex virus type-1 infection. Phytother Res. 2013; 24(8):1132-1140.

86. Ahmad A, Javed MR, Rao AQ, Husnain T. Designing and screening of universal drug from neem (Azadirachta indica) and standard drug chemicals against influenza virus neucleoprotein. BMC Complement Altern Med. 2016; 16:519. doi:10.1186/s12906-016-1469-2

87. Bode AM, Dong Z. The Amazing and Mighty Ginger. In: Benzie IFF, Wachtel-Galor S, editors. Herbal Medicine: Biomolecular and Clinical Aspects. 2nd edition. Boca Raton (FL): CRC PressTaylor \& Francis; 2011. Ch.7.

Available from:

https://www.ncbi.nlm.nih.gov/books/NBK92775/

88. Young H. Y, Luo Y. L, Cheng H. Y, Hsieh W. C, Liao J. C, Peng W. H. Analgesic and anti-inflammatory activities of [6]-gingerol. $J$ Ethnopharmacol. 2005;96(1-2):207-10. [PubMed]

89. Sahoo M, Jena L, Rath S.N, Kumar S. Identification of suitable natural inhibitor against influenza A (H1N1) neuraminidase protein by molecular docking. Genomics inform. 2016;14(3):96-103. doi: 10.5808/GI.2016.14.3.96

90. Chang J.S, Wang K.C, Yeh C.F, Shieh D.E, Chiang L.C. Fresh ginger (Zingiber officinale) has anti-viral activity against human respiratory syncytial virus in human respiratory tract cell lines. J Ethnopharmacol. 2013; 145(1):146-151. [PubMed]

91. Denyer C.V, Jackson P, Loakes D.M, Ellis MR, Young D.A. Isolation of antirhinoviral sesquiterpenes from ginger (Zingiber officinale). J Nat Prod. 1994; 57(5):658-662. [PubMed]

92. Townsend EA, Siviski ME, Zhang Y, Xu C, Hoonjan B, Emala CW. Effects of ginger and its constituents on airway smooth muscle relaxation and calcium regulation. Am J Respir Cell Mol Biol. 2013; 48(2):157-163. doi:10.1165/rcmb.2012-02310C

93. Cifci A, Tayman C, Yakut Hi, et al. Ginger (Zingiber officinale) prevents severe damage to the lungs due to hyperoxia and inflammation. Turk J Med Sci. 2018;48(4):892-900. doi:10.3906/sag-1803-223

94. Khan AM, Shahzad M, Raza Asim MB, Imran M, Shabbir A. Zingiber officinale ameliorates allergic asthma via suppression of Th-2-mediated immune response. Pharm Biol. 2015; 53(3):359-367. doi:10.3109/13880209.2014.920396

95. Rao P.V, Gan S.H. Cinnamon: a multifaceted medicinal plant. Evid Based Complement Alternat Med. 2014; 2014:642942. dio: 10.1155/2014/642942

96. Schink A, Naumoska K, Kitanovski Z, et al. anti-inflammatory effects of cinnamon extract and identification of active compounds influencing the TLR2 signaling pathways. Food Funct. 2018; 9(11):5950-5964. [PubMed]

97. Han X, Parker T.L. Anti-inflammatory activity of cinnamon (Cinnamomum zeylanicum) bark essential oil in human skin. Phytother Res. 2017; 31(7):1034-1038. [PubMed] 
98. Gunawardena D, Karunaweera N, Lee $\mathrm{S}$, et al. antiinflammatory activity of cinnamon (C. zeylanicum and C. cassia) extracts- identification of E-cinnamaldehyde and omethoxy cinnamaldehyde as the most potent bioactive compounds. Food Funct. 2015;6(3):910-919. [PubMed]

99. Fatima M, Zaidi NU, Amraiz D, Afzal F. In vitro antiviral activity of cinnamomum cassia and its nanoparticles against H7N3 influenza A virus. J Microbiol Biotechnol. 2016; 26(1):151-159. [PubMed]

100. Brochot A, Guilbot A, Haddioui L, Roques C. Antibacterial, antifungal and antiviral effects of three essential oil blends. Microbiologyopen. 2017; 6(4):e00459. [PubMed]

101. Fauvelle C, Lambotin M, Heydmann L, et al. A cinnamon derived procyanidin type A compound inhibits hepatitis $C$ virus cell entry. Hepatol Int. 2017; 11(5):440-445. [PubMed]

102. McKay DL, Blumberg JB. A review of the bioactivity and potential health benefits of peppermint tea (Mentha piperita L.). Phytother Res. 2006; 20(8): 619-633. [PubMed]

103. Schhmacher A, Reichling J, Schnitzler P. Virucidal effect of peppermint oil on the enveloped viruses herpes simplex virus type 1 and type 2 in vitro. Phytomedicine. 2003; 10(6-7): 504510. [PubMed]

104. Li YX, Liu YB, Ma AQ. Bao Y, Wang M, Sun ZL. In vitro antiviral, anti-inflammatory, and antioxidant activities of the ethanol extract of Mentha piperita L. Food Sci Biotechnol. 2017; 26(6): 1675-1683. [PubMed]

105. Ibne Sena. Alqanoonfittib. Urdu translation by GhulamHasnainkantoori. New Delhi: Ejaz publishing house; 2010; 91):464.

106. Shang A, Cao SY, Xu XY, et al. Bioactive compounds and biological functions of garlic (Allium sativum L.). Foods. 2019, 8(7):246. doi:10.3390/foods8070246

107. Tsai Y, Colle LL, Davis LE, Lockwood SJ, Simmons V, Wild GC. Antiviral properties of garlic: In vitro effects on influenza B, Herpes simplex and Coxsackie viruses. Planta Med. 1985; 51(5):460-461. doi: 10.1055/s-2007-969553

108. Weber ND, Anderson DO, North JA, Murray BK, Lawson LD, Hughes BG. In vitro virucidal effects of Allium sativum (garlic) extract and compounds. Planta Med. 1992; 58(5):417-423. doi:10.1055/s-2006-961504

109. Guo NL. Lu DP, Woods GL, et al. demonstration of the antiviral activity of garlic extract against human cytomegalovirus in vitro. Chin Med J (Engl). 1993; 106(2):93-96. [PubMed]

110. Shojai TM, Langeroudi AG, Karimi V, Barin A, Sadri N. The effect of Allium sativum (garlic) extract on infectious bronchitis virus in specific pathogen free embryonic egg Avicenna J Phytomed. 2016; 6(4):458-267. [PubMed]

111. Nejad ASM, Shabani S, Bayat M, Hosseini SE. Antibacterial effect of garlic aqueous extract on Staphylococcus aureus in Hamburger. Jundishapur J Microbiol. 2014; 7(11):e13134. doi: 10.5812/jjm.13134

112. Yadav S, Trivedi NA, Bhatt JD. Antimicrobial activity of fresh garlic juice: An in vitro study. Ayu. 2015; 36(2):203-207. doi: 10.4103/0974-8520.175548

113. Lu X, Rasco BA, Jabal JMF, Aston DE, Lin M, Konkel ME. Investigating antibacterial effects of garlic (Allium sativum) concentrate and garlic derived organosulfur compounds on campylobacter jejuni by using fourier transform infrared spectroscopy, Raman spectroscopy, and electron microscopy. Appl Environ Microbiol. 2011; 77(15):5257-5269. doi: 10.1128/AEM.02845-10

114. El-Azzouny MM, El-Demerdash AS, Seadawy HG, Abou-Khadra SH. Antimicrobial Effect of garlic (Allium sativum) and thyme (Zataria multiflora Boiss) extract on some food borne pathogens and their effect on virulence gene expression. Cell Mol Biol (Noisy-le-grand). 2018; 64(10):79-86. [PubMed]

115. Kshirsagar MM, Dodamani AS, Karibasappa GN, Vishwakarma PK, Vathar JB, Sonawane KR, et al. antibacterial activity of garlic extract on carcinogenic bacteria: An in vitro study. Ayu. 2018; 39(3):165-168. doi:10.4103/ayu.AYU-193-16

116. Jang HJ, Lee HJ, Yoon DK, Ji DS, Kim JH, Lee CH. Antioxidant and antimicrobial activities of fresh garlic by-products extracted with different solvents. Food Sci Biotechnol. 2018; 27(1):219-225. doi:10.1007/s10068-017-0246-4

117. Kang J.S., Kim S.O., Kim G.Y., Hwang H.J., Kim B.W., Chang Y.C., Kim W.J., Kim C.M., Yoo Y.H., Choi Y.H. An exploration of the antioxidant effects of garlic saponins in mouse-derived C2C12 myoblasts. Int. J. Mol. Med. 2016; 37:149-156. doi: 10.3892/ijmm.2015.2398. [PubMed]

118. Naji K.M., Al-Shaibani E.S., Alhadi F.A., Al-Soudi S.A., D’Souza M.R. Hepatoprotective and antioxidant effects of single clove garlic against ccl4-induced hepatic damage in rabbits. BMC Complement. Altern. Med. 2017; 17:411. doi: 10.1186/s12906-017-1916-8. [PubMed]

119. Schafer G, Kaschula $\mathrm{CH}$. The immunomodulation and antiinflammatory effects of garlic organosulphur compounds in cancer chemoprevention. Anticancer Agents Med Chem. 2014; 14(2):233-240. doi:10.2174/18715206113136660370

120. Mahima, Rahal A, Deb R. et al. immunomodulatory and therapeutic potential of herbal, traditional/indigenous and ethnoveterinary medicines. Pakistan Journal of Biological Sciences. 2012; 15(16):754-774 doi:10.3923/pjbs.2012.754.774.

121. Hofbauer R. Frass M. Gmeiner B. Kaye AD. Frost EA. Effects of garlic extract (Allium sativum) on neutrophil migration at the cellular level. Heart Dis. 2001; 3:14-17. [PubMed]

122. Lee DY, Li H, Lim HJ, Lee HJ, Jeon R, Ryu JH. Anti-inflammatory activity of sulfur- containing compounds from garlic. J Med Food. 2012; 15(11):992-999. doi:10.1089/jmf.2012.2275

123. Surh YJ. Chun KS. Cha HH, et al. Molecular mechanisms underlying chemopreventive activities of anti-inflammatory phytochemicals: down-regulation of COX-2 and iNOS through suppression of NF-kappa B activation. Mutat Res. 2001:480481. 243-268. [PubMed]

124. Islam MN, Yadav RL, Yadav PK. Modulation of lung function by increased nitric oxide production. J Clin Diagn Res. 2017; 11(6):CC09-CC12. doi:10.7860/JCDR/2017/24650.9981

125. Saastamoinen M, Sarkijarvi S, Hyyppa S. Garlic (Allium sativum) supplementation improves respiratory health but has increased risk of lower hematologic values in horses. Animals (Basel). 2019; 9(1):13. doi:10.3390/ani9010013

126. Lissiman E, Bhasale AL, Cohen M. Garlic for the common cold. Cochrane database Syst Rev. 2014;2014(11):CD006206. doi:10.1002/14651858CD006206.pub4

127. Hsieh CC, PengWH, Tseng HH, Liang SY, Chen LJ, Tsai JC. The protective role of garlic on allergen-induced airway inflammation in mice. Am J Chin Med. 2019; 47(5):1099-1112. doi:10.1142/S0192415X19500563

128. Zare A, Farzaneh P, Pourpak Z, et al. Purified aged garlic extract modulates allergic airway inflammation in BALB/c mice. Iran J Allergy Asthma Immunol. 2008; (3):133-141. [PubMed]

129. Takoori H, Aumeeruddy MZ, Rengasamy KRR, et al. a systemic review on black pepper (Piper nigrum L.): from folk uses to pharmacological applications. Crit Rev Food Sci Nutr. 2019; 59(1):S210-S243. [PubMed]

130. Kesarwani K, Gupta R. Bioavailability enhancers of herbal origin: An overview. Asian Pac J Trop Biomed. 2013; 3(4):253266. [PubMed]

131. Gulcin I. The antioxidant and radical scavenging activities of black pepper (piper nigrum) seeds. Int J Food Sci Nutr. 2005; 56(7):491-499. [PubMed]

132. Singh R, Singh N, Saini B.S, Rao H.S. In vitro antioxidant activity of pet ether extract of black pepper. Indian $J$ Pharmacol. 2008; 40(4):147-151. [PubMed]

133. Tasleem F, Azhar I, Ali SN, Perveen S, Mahmood ZA. Analgesic and anti-inflammatory activities of piper nigrum L. Asian Pac J Med. 2014; 7S1:S461-S468. doi :10.1016/S19957645(14)60275-3

134. Bang JS, Oh DH, Choi HM, et al. anti-inflammatory and antiarthritic effects of piperine in human interleukin $1 \beta$ stimulated fibroblast-like synoviocytes and in rat arthritis models. Arthritis Res Ther. 2009; 11(2):R49. [PubMed]

135. Zou L, Hu YY, Chen WX. Antibacterial mechanism and activities of black pepper chloroform extract. J Food Sci Technol. 2015; 52(12): 8196-8203. [PubMed]

136. Tang H, Chen W, Dou ZM, et al. Antimicrobial effect of black pepper petroleum ether extract for the morphology of Listeria monocytogenes and Salmonella typhimurium. J Food Sci Technol. 2017; 54(7):2067-2076. [PubMed]

137. Mair EM, Liu R, Atanasov AG, et al. Antiviral and antiproliferative in vitro activities of piperamides from black pepper. Plant Medica. 2016; 81(S01):S1-S381. [PubMed] 
138. Bhattacharya SK, Goel RK, Kaur R, Ghosal S. Anti - stress activity of Sitoindosides VII and VIII. New Acylsterylglucosides from Withania somnifera. Phytother Res. 1987; 1:32-37.

139. Ghosal S, Srivastava RS, Bhattacharya SK, Upadhyay SN, Jaiswal AK, Chattopadhyay U. Immunomodulatory and CNS effects of sitoindosides IX and X, two new glycowithanolides form Withania somnifera. Phytother Res. 1989; 2:201-206.

140. Singh N, Bhalla M, de Jager P, Gilca M. An overview on ashwagandha: a Rasayana (rejuvenator) of Ayurveda. Afr J Tradit Complement Altern Med. 2011; 8(5 Suppl):208-213. doi:10.4314/ajtcam.v8i5S.9

141. Ziauddin M, Phansalkar N, Patki P, Diwanay S, Patwardhan B. Studies on the immunomodulatory effects of Ashwagandha. J Ethnopharmacol.1996; 50(2):69-76.

142. Cai Z, Zang G, Tang B, Liu Y, Fu X, Zhang X. Promising antiinfluenza properties of active constituent of Withania somnifera Ayurvedic herb in targeting neraminidase of H1N1 influenza: computational study. Cell Biochem Biophys. 2015; 72(3):727-739.

143. Marauder A, Ganzera M. Quantitative determination of major alkaloids in cinchona bark by supercritical fluid chromatography. J Chromatogr A. 2018; 117-122. doi:10.1016/j.chroma.2018.04.038
144. An J, Minie M, Sazaki T, Woodward JJ, Elkon KB. Antimalarial drugs as immune modulators: New mechanism for older drugs. Ann Rev Med. 2017; 68:317-330. doi:10.1146/annurev-med-043015-123453

145. Wen CC, Kyo YH, Jan JT, et al. Specific plant terpenoids and lignoids possess potent antiviral activities against severe acute respiratory syndrome coronavirus. J. Med. Chem. 2007; 50:4087-4095.

146. Khaerunnisa S, Kurniawan H, Awaluddin R, Suhartati S, Soetjipto S. Potential inhibitor of COVID-19 main protease (Mpro) from several medicinal plant compounds by molecular docking study. Preprints [internet][updated March 13, 2020]. Cited on March 31, 2020. doi:10.20944/preprints202003.0226.v1

147. Ni L, Zhou L, Zhou M, Zhao J, Wang DW. Combination of western medicine and Chinese traditional patent medicine in treating a family case of COVID-19 in Wuhan. Front Med. 2020; doi:10.1007/s11684-020-0757-X

148. Yang Y, Islam MS, Wang J, Li Y, Chen X. Traditional Chinese Medicine in the treatment of patients infected with 2019-New Coronavirus (SARS-CoV-2): a review and perspective. Int J Biol Sci. 2020; 16(10):1708-1717. Doi:10.7150/ijbs.45538 